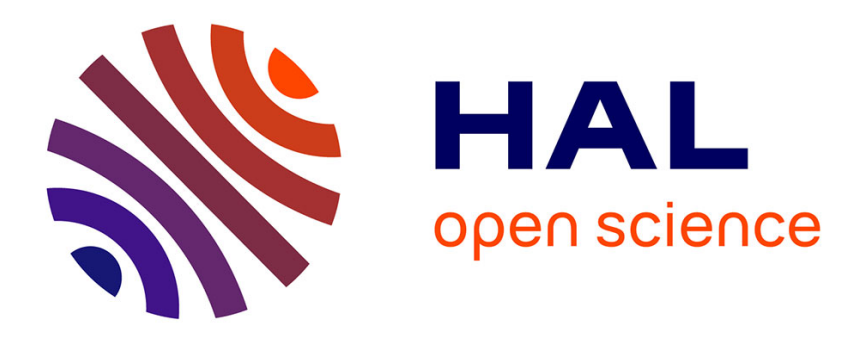

\title{
Transborder Dwelling in Albina (Suriname) and Saint-Laurent (French Guiana) on the Lower Maroni
}

Clémence Léobal

\section{To cite this version:}

Clémence Léobal. Transborder Dwelling in Albina (Suriname) and Saint-Laurent (French Guiana) on the Lower Maroni. Ekaterina Mikhailova; John Garrard. Twin Cities Across Five Continents, Routledge, 2021, 978.0.367.60922.1. hal-03095177

\section{HAL Id: hal-03095177 https://hal.science/hal-03095177}

Submitted on 3 Jan 2022

HAL is a multi-disciplinary open access archive for the deposit and dissemination of scientific research documents, whether they are published or not. The documents may come from teaching and research institutions in France or abroad, or from public or private research centers.
L'archive ouverte pluridisciplinaire HAL, est destinée au dépôt et à la diffusion de documents scientifiques de niveau recherche, publiés ou non, émanant des établissements d'enseignement et de recherche français ou étrangers, des laboratoires publics ou privés. 


\title{
Transborder Dwelling in Albina (Suriname) and Saint-Laurent (French Guiana) on the Lower Maroni \\ Clémence Léobal
}

\begin{abstract}
This chapter focuses on daily life in twin cities spanning a European border, where the same living space (the Maroni river) became administratively separated at the time of Suriname's independence in 1975. Its approach is to look more specifically at the concrete and daily implications of life in twin cities for the Ndjuka working-class inhabitants, and their perception and experience. Forms of transnationalism at a local scale also involve kinship relations. Building on Marcelin's concept of "configuration of houses", this analysis is based on a ethnographic case-study of one large family who lives on both sides and show how they dealt with the political border and how the border affected them. First, I describe this group's conceptualization of living on the border in a configuration of houses straddling both sides. I then explore the circumstances, both private and administrative, forcing on of its female member to return to her maternal family on the Surinamese side. Finally, I examine the experiences of this woman and other border inhabitants facing the complex entanglement of State administration policies on houses, healthcare, social benefits and land-access.
\end{abstract}

Bio Clémence Léobal is a sociologist, permanent member of the French National Center for Scientific Research. She belongs to the Lavue (Nanterre University). Her work on French Guiana began in 2009, when she was employed by the Saint-Laurent-du-Maroni town hall to prepare its Center for the Interpretation of Architecture and Heritage. In her $\mathrm{PhD}$ thesis, defended in 2017, she analyzed together the implementation of urban policies and their reappropriation by bushinenge inhabitants. Her current research focuses on the way in which the border takes on concrete consistency through the diversity of the administrative network and its uses on the Maroni. 
Until very recently, the Maroni River was a porous border between French Guiana and Suriname, a now-independent former Dutch colony. Like many post-imperial Caribbean borderlands, this porosity existed despite the authorities' best efforts at immigration and commercial-exchange control. However, in March 2020, the global COVID-19 pandemic succeeded where French authorities had failed, closing the border for the first time in its history. In March 2020, Surinamese authorities imposed a near-total ban on Albina-to-Saint-Laurent pirogue crossings (wooden boats). As of June 2020, this has caused major food shortages on the French Guianese riverside and mass unemployment on the Surinamese side.

Before closure, local populations both crossed the river and also inhabited its banks and islands. As such, according to the habiter concept, meaning activity of building a territory in the world (Hoyaux, 2002), they were creating an intimate relationship with opposite places.

Situated on the Maroni estuary, the twin towns of Saint-Laurent-du-Maroni and Albina are inhabited by people who continually crossed this 5 kilometres-wide river. The Ndyuka are one of the Maroon groups that fled (and fought) Suriname plantation-owners. Nowadays, they say they 'wear' French or Surinamese nationality, meanwhile identifying as Ndyuka, an independently conceptualized identity connected to territories upriver where the Dutch Republic through the 1762 peace treaty recognised their sovereignty. The Maroni Basin is populated by Amerindians and Maroons, both of whom resisted colonialism and lived largely autonomously from their respective State governments (Piantoni, 2009). In recent decades, these ethnic groups have undergone profound social transformations due to mass migration to towns along the river. Maroon ethnic groups have created a transborder territory along this political border; characterized by the omnipresence of the two 'sides', sharing a common language (Migge and Léglise, 2019). The Ndyuka concept of liba means both 'river' and 'inhabited territory'. The river is thus considered less a division than a link between two banks. While the Ndyuka (among Maroon and Amerindian groups) inhabit both banks, the administrative border linking them separates a European country (French Guiana is part of France) from Suriname, an independent Third-World republic.

The Maroni border is 525 kilometres long, and contested by Suriname in the upriver zones. Immigration rules applying here are based on French law but much stricter than those in metropolitan France: there are many derogations reinforcing immigration-control (Benoît, 2015). However, the rules have very low effectivity due to high cross-border mobility. The Police aux Frontières certainly do not check all boats crossing the river. Since 1985, the official border-post has been located in Iracoubo, 110 kilometres up the Saint-Laurent-to-Cayenne road.

Transborder ways of dwelling are broadly shared among all those on the estuary, including the 
working classes, Maroons, Kali'na Amerindians (Collomb and Renault-Lescure, 2014), Haitians (Laethier, 2014), Brazilians (Heemskerk and Theije, 2009) and the local transnational elite (Chinese traders and Surinamese entrepreneurs). I focus on these towns' day-to-day life, where common living-space became administratively separated upon Surinamese independence in 1975, examining the concrete, day-to-day implications of living there for Ndyuka working-class inhabitants along with their perceptions and experiences. At local level, transnationalism (Glick Schiller et al, 1992) involves borderlanders' pride in being able to navigate between Suriname and French Guyane, but also ethnic pride to be Maroon. It involves kinship relations as well. Inhabiting the Maroni thus entails ways of dwelling within larger kinship groups, involving solidarity but also tensions, power relations, conflict and dysfunction. In her study of the Mexican-US border, Whiteford invented the concept of 'extended community' to analyse how kinship networks transcended barbed wire (Whiteford, 1979). Here, I draw on this but also build on Marcelin's concept (Marcelin, 1996), where people do not live just in single houses but multiple houses. Connecting kinship anthropology and residential geography, it helped analyse local ways of border-negotiation. The concept was associated with mobility, circulations and tensions (Motta, 2014) and included governing modes that were both private (governing the house) and public (border policies). These configurations were shaped by familial conflicts involving class and national divisions intertwined with border policies.

This analysis is based on a case-study of one large family I met in Saint-Laurent-du-Maroni, the largest town on the French Guianese side. This family group had also built a small village on the Surinamese side, close to the twin town of Albina. I will show how they dealt with the political border and how the border affected them. Their residential choices were underpinned by administrative opportunities and constraints. I conducted an ethnographic study in 2013/14, following one family member, Lena, through her various displacements and pursuit of official documents.

First, I describe this group's conceptualization of living on the border in a configuration of houses straddling both sides. I then explore the circumstances, both private and administrative, forcing Lena to return to her maternal family on the Surinamese side. Finally, I examine the experiences of Lena and other border inhabitants facing the complex entanglement of State administration policies on houses, healthcare, social benefits and land-access.

\section{'Eating from Both Lands': Transnational Lives}

'If the State demolishes my house, I'll build a stilt house on the river'. These were the words of Lili, a female elder living in Saint-Laurent-du-Maroni. Her house was threatened with demolition because the French Guianese authorities considered it illegal. Lili had no building permit, no title- 
deed or land-tenure, no personal authorization to live on French territory. Beyond her proposal's humorous overtones (stilt dwellings are no longer constructed in the town), she underscored her conceptualization of inhabiting the border with her projection 'on the river'.

I first went to Lebi Doti, a peripheral neighbourhood, to visit Lili's niece-in-law, Lena, a 25-year-old Ndyuka woman. I had made contact through Diane Vernon, an anthropologist working in the local hospital culturally mediating between patients and medical staff. She introduced me to Lena, who lived in a sector set for demolition. Lena regularly visited the hospital because of her disabled child. Lena was being accommodated by Lili, her husband's aunt, and they lived with many relatives in two houses. Over frequent visits, I came to understand that Lena occupied a marginalized position among them. A year later, she moved back to the Surinamese bank due to familial pressure alongside the administrative deadlock she faced as an undocumented person.

Although telling her many times I was not working for either local administration but for a Paris university, Lena expected me to help her secure social housing and residence-documents, seeing me as a White (bakaa) woman somehow connected with the State. I felt guilty being unable to help more. The little I could provide for these inhabitants (e.g., occasionally purchasing food and medicines) was incommensurate with the invaluable thoughts they shared on border life during our afternoon discussions.

Lili had spent her whole life on one or other riverside. She never called this space a border, referring instead to its 'two sides'. One afternoon, as we sat on her terrace with her sister, she said, laughing: 'I'm eating from both lands'. This expression normally justifies male polygamy: 'eating from' different women. Lili, a widow, had taken it from its gender-relations context: inversing the implied power-relation, rendering herself superior in this two-sided territory, enjoying both lands simultaneously like polygamous Maroon men. This reveals her sense of belonging and mastery within the Maroni-River territory, much greater than the simple boundary depicted in State cartography (see figure 1). 
Figure 1: Lili's trajectory through civil war.

Source: Map by Clémence Léobal.

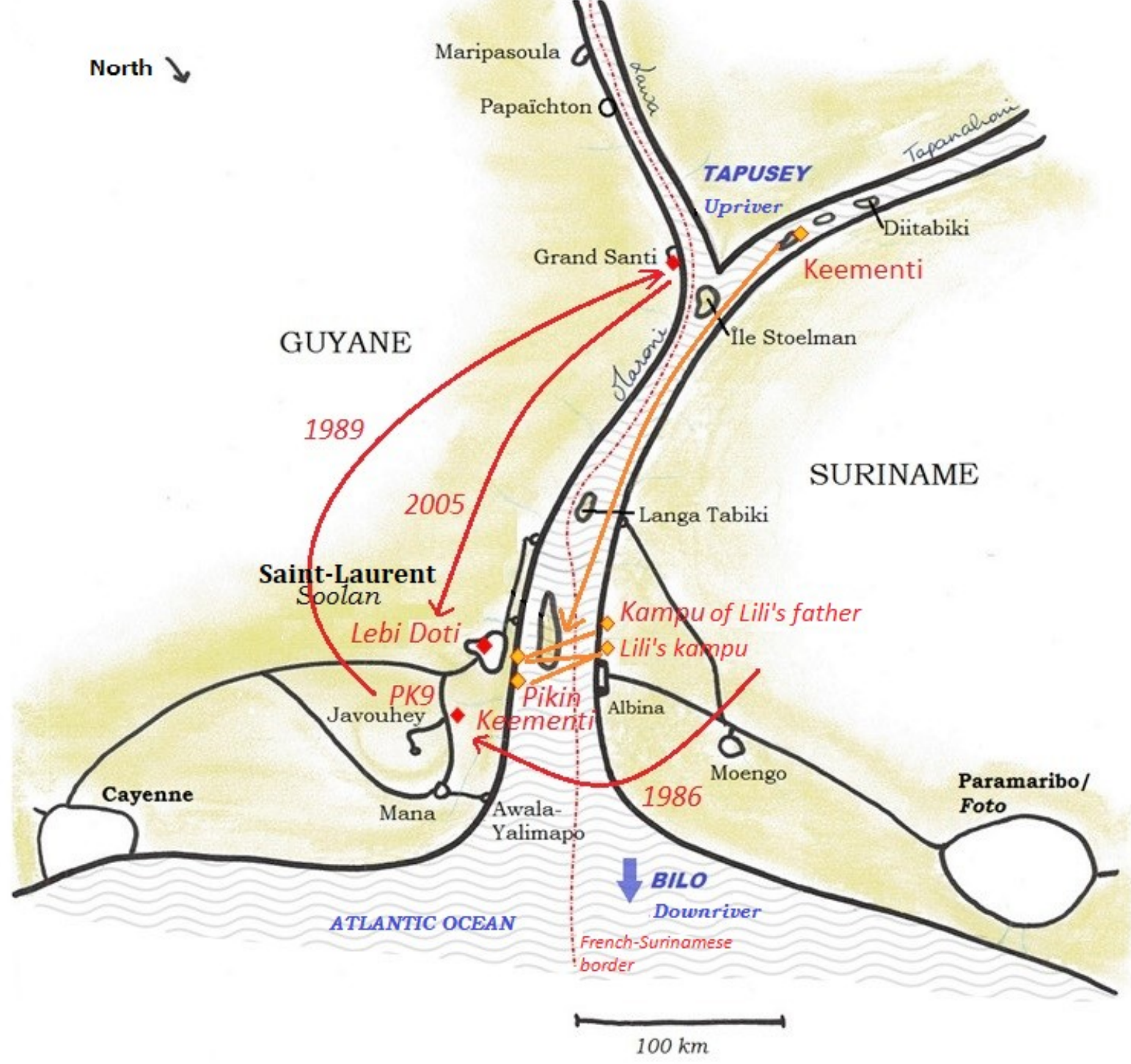

Relocation before Surinamese civil war

Relocation after Surinamese civil war

\section{Mapping the Border}

Based on cognitive mapping (Aberley, 1993), these drawings spatially represent elements from my ethnographic research. The handmade representation underlines the constructional nature of any cartography. My drawings, do not attempt precise topography, though respectful of approximate kilometric scales. I forego the conventional northerly orientation of maps, instead orienting upriver, respecting inhabitants' perceptions conceiving places according to their river location. In the Ndyuka language, people either go upriver (opusey) or downriver (bilo). 


\section{Living Together in Several Houses}

Lebi Doti was reached by a lateritic path called Piste des Vampires. Winding through dense vegetation, this path was not exactly an urban landscape. Lena and Lili lived in two houses perched on a hilltop. This 'hill' was actually an earth-mound bequeathed by a development company's bulldozers, which were already levelling the ground for three-storey buildings. The two wooden houses were divided into four homes. Franz lived in one house with his wife and ten children. The other was partitioned into three homes for Lili, Lena (plus husband and three children) and one of Lili’s nephews' wives.

According to Marcelin, within such a configuration, the houses' inhabitants engage in relations comprising exchanges of goods and services. They can eat, sleep, circulate and leave children to be looked after within each other's houses. These configurations nevertheless can be changed by life events and conflicts within the group. Lena was dwelling together with other people. There were many exchanges between the four homes. Children circulated from one to another hoping to be fed whenever dishes were prepared. All the women would periodically care for each other's children, especially Lena's third child, Gabriella, whose illness rendered her insensitive to pain. Lena was often without resources because neither she nor husband Bobby had residence documents or received state benefits. In using the terms 'husband', 'wife' or 'marriage' here, I refer to a nonadministrative Ndyuka union, contracted in a ceremony between the couple's respective matrilineages. Bobby sometimes worked a 'job' driving someone's boat or building a house. Lili sometimes gave Lena a little of what she needed to feed her children. Franz and his wife also gave her products from their fields. However, this mutual assistance had limits. Lena had to go to community services that distributed food, mostly macaroni (which she hated). She could not count solely on neighbours' help.

\section{Configurations of Houses across Urban and National Borders}

Lena actually lived within two distinct configurations, her husband's in Lebi Doti and those of maternal relatives. Both extended across urban boundaries into other neighbourhoods and over the River.

Lebi Doti's inhabitants also lived closely connected with other houses in the town. They often visited Ine, Lili's sister and Lena's mother-in-law. She lived on the Piste des Vampires's opposite side. One of Lena's daughters took me there on my first visit, leading me along a winding path. Just 5 years old, she was used to going to see her grandmother by herself without asking permission, showing how often Ine looked after her. The extensive exchanges between Ine and Lili also resulted from past cohabitation. A few years before, after separating from her husband, Ine had lived at her sister's until one of Lili's friends 'gave' Ine some land so she could build a house - even though, as 
with Lebi Doti and most of the rest of French Guiana, the land was legally French State property. When I returned to the field a year later, Lili was unwell and being accommodated and looked after by Ine. One of Ine's daughters had replaced Lily in her former house in Lebi Doti. The houses' occupants thus frequently moved in and out depending on life events (see Figure 2). This changing configuration resulted from changing relationships. Lena and Bobby had come to Lebi Doti in 2011, replacing one of Lili's other nieces, Kiki. Bobby had lived there with Lili as a young boy. The present configuration thus resulted partly from past arrangements.

Figure 2: Lena's kinship tree

Source: Drawing by Clémence Léobal

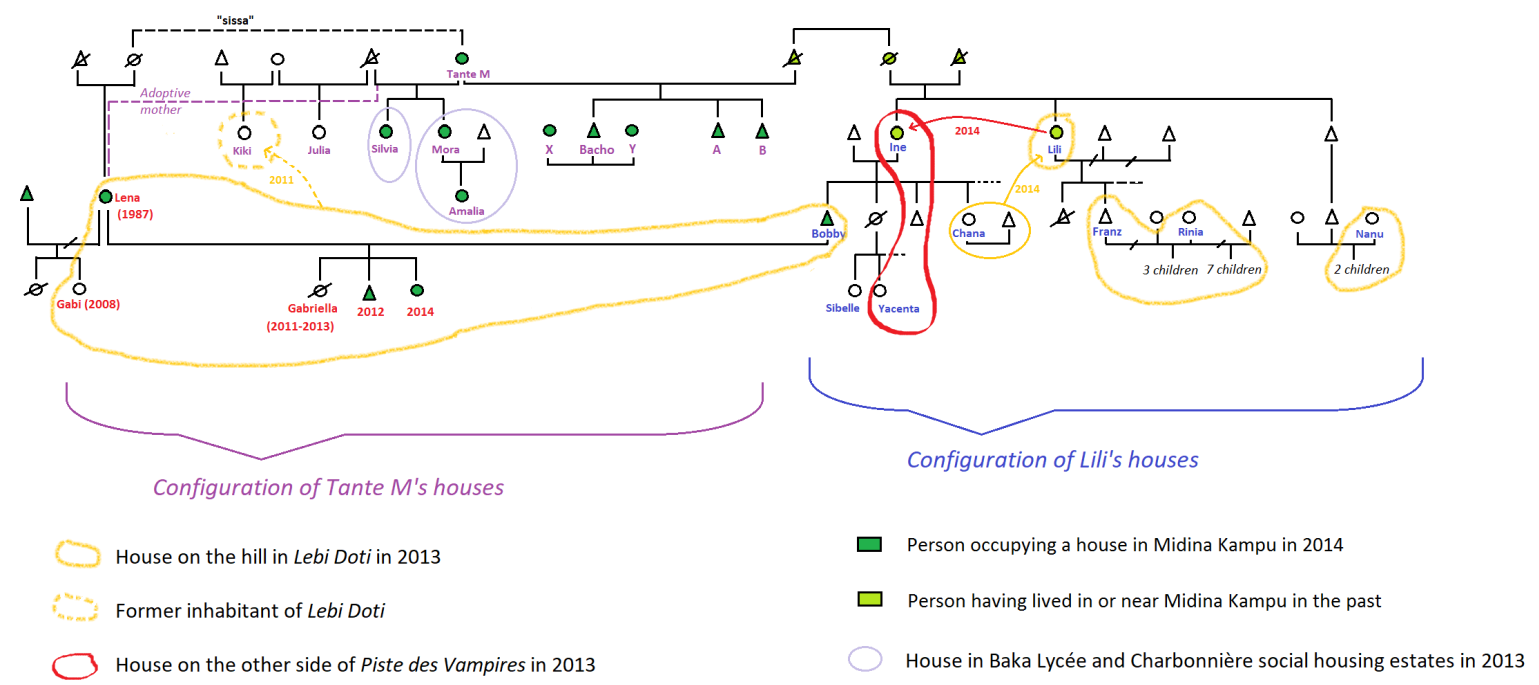

Lena also visited the configuration inhabited by her foster sisters in Baka Lycée, a social-housing estate 15 minutes' walk from Lebi Doti. Lena had lived there in the past with her sissa (sister or cousin) Silvia. Silvia was Lena's foster-mother's daughter, who had raised Lena in Suriname and whom she called Tante ('aunt' in Dutch). Fostering was common in Maroon societies resulting in children being redistributed within or outside the matrilineage (Vernon, 1992). Silvia lived in an individual State-owned house, which she had extended to accommodate several homes. Lena and Bobby visited several times weekly, for example to charge their phones: Lebi Doti being without electricity. The relatives had also gathered at Silvia's house when Lena's disabled child died in July 2013. During family crises, Lena also visited another estate further away called Charbonnière to see Silvia's sister, Mora. When Mora's daughter Amalia was hospitalised following a miscarriage, Lena visited her several times. Lena thus certainly lived in a configuration of houses: indeed, as I later discovered, moving back and forth between two configurations, that of Bobby's relatives, including Lili, Franz and Ine, and that of her foster mother's relatives.

These configurations extended not only over urban boundaries but also over the national border. Lili, Lena and her relatives had houses in a village across the river called Midina kampu. When I 
visited, both women spoke fondly of this village, describing it as a peaceful place with a beautiful creek to bathe in. Both had lived there, Lili in her own kampu very close to the current Midina kampu, until the Surinamese 1986 civil war destroyed it. She said 'the war dispersed the house', meaning everyone had gone their own ways. She subsequently moved to the French side, and her sister Ine moved to Paramaribo. .

Lena and Lili lived closely connected with the surviving Midina kampu, which was included in their configuration. Lena visited the kampu very regularly. Her Tante had a house there as well as in Paramaribo. Many of the Tante's children had houses in the kampu, including Silvia and Mora, who also had social-housing accommodation in Saint-Laurent. The kampu inhabitants regularly came to Saint-Laurent, only thirty minutes away by boat. The kampu was also linked to Albina by a muddy track. The fifteen-minute taxi-ride from the kampu to Albina cost twenty euros, and the five-minute boat trip from Albina to Saint-Laurent three euros. A man once came from the kampu to Lebi Doti in his boat to deliver his sisters to the hospital to look after Amalia, who had miscarried. Their modes of dwelling thus involved solidary exchanges between houses from both sides of the river.

This family group was appropriating this transborder space. Some like Lena's Tante, had multiple residences (see fig. 3, which reflects the situation during my research and especially from Lena's viewpoint). Mora and Silvia had houses in the kampu and on the French side, where their children attended school. They came to the kampu for holidays and weekends to relax or work in the fields. Both Surinamese and French mobile-phone networks were available in the lower Maroni region facilitating cross-river integration. Most people had two phones enabling calls in either French Guiana or Suriname. 
Figure 3: Lena's transborder configuration of houses and trajectory

Source: Map by Clémence Léobal

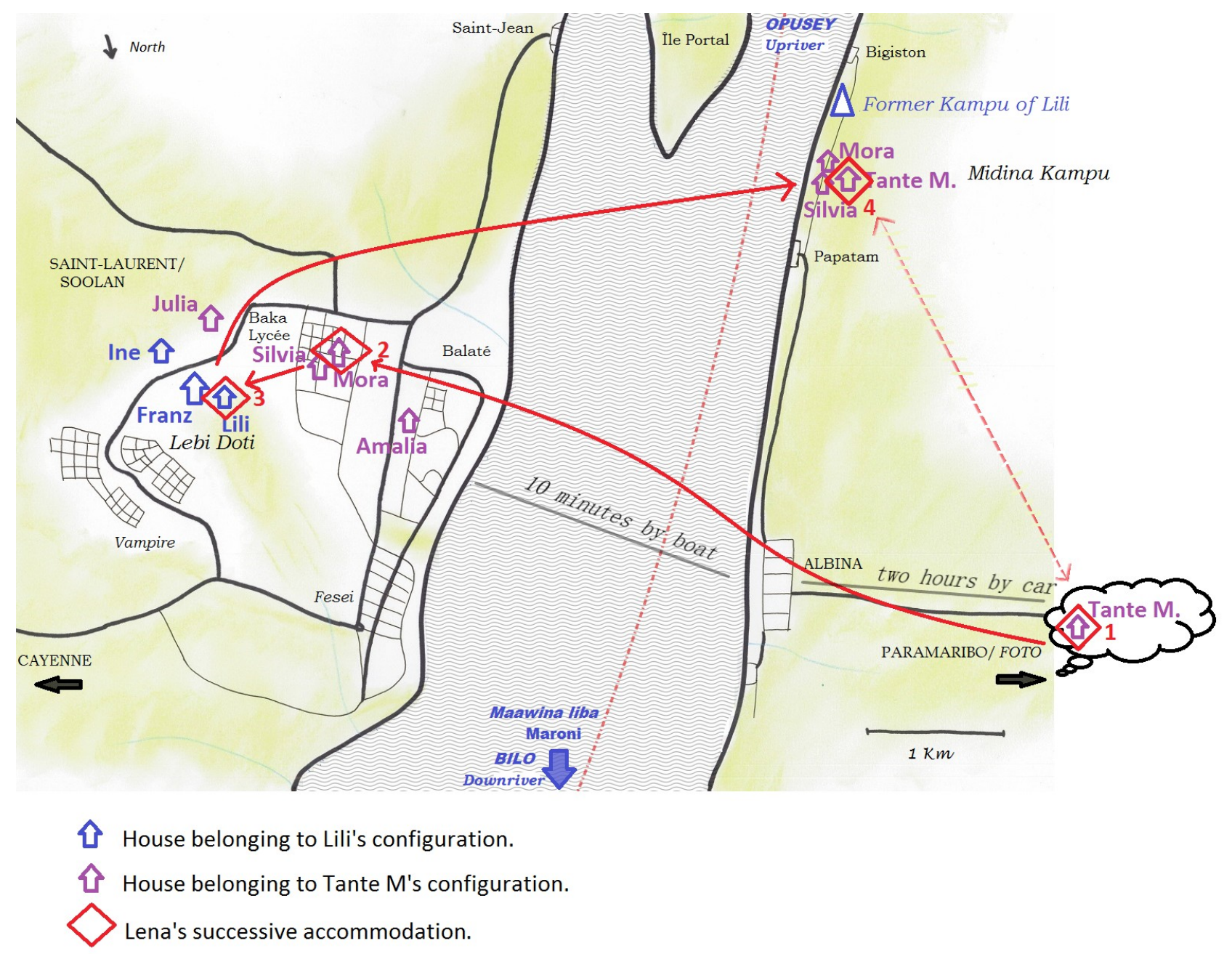

\section{Border Policies and Familial Conflicts Intertwined}

Why did Lena move between banks in 2014? The configurations were shaped by conflict and combined different logics, including immigration and border-control policies making it impossible for Lena to obtain residence documents. Furthermore internal pressures within the configuration placed many demands on Lena regarding her financial autonomy, motherhood skills and general respectability. These family-group tensions were unspoken in my presence. Only during the crisis triggered by Lena's child dying were they expressed aloud. They were nevertheless constitutive of the housing configurations. Mutual assistance and solidarity entail individual costs (Gollac, 2003), even accompanying forms of 'tyranny' (Douglas, 1991). Lena was doubly excluded, from Lili's configuration and from the French riverbank.

I understood the distinction between Lili's and Lena's Tante's side only after Lena's child died at the end of my first fieldwork-stay in July 2013: when I returned after the ensuing crisis in 2014 I 
noticed Lena had moved from Lebi Doti to her Tante's in Midina kampu. The configuration of houses, including Mora's, Silvia's and Lena's, was reproduced on a different scale here. One entire neighbourhood of the kampu constituted what they called Lena's Tante's Ma bee: bee meaning 'belly' also refers to the 'lineage' or the neighborhood formed by a $M a$ (woman) and her descendants. Her house stood amidst an array of houses belonging to her children and other relatives. Mora and Silvia thus supported Lena in Saint-Laurent because of their common relationship to Tante's as attested by the layout of the houses in Midina kampu. Lili and her relatives had supported Lena because she was Bobby's wife.

This distinction was difficult to perceive because of an earlier alliance between these two groups. Lena's Tante had been married to Lili's maternal uncle. Hence, all members of both configurations where Lena lived were inter-related. This alliance explains how Bobby, Ine's son, was raised by his great-uncle in the kampu, where he met Lena. Lili had not returned to that side of the river since the war, but still had relatives there. Lena was raised by her Tante, to-ing and fro-ing between her houses in the kampu and Paramaribo. This was how Lena met her two husbands. She had first come to Saint-Laurent in 2003 to have her eldest daughter treated at the hospital (she died a few years before I met Lena). When her third daughter, Gabriella, began suffering the same illness, Lena's relatives held her responsible, believing her a bad mother, too lazy to work or get her residence documents. Diane Vernon told me later Lena was held responsible for her child's illness because her first husband was a maternal cousin, strongly prohibited by Ndyuka custom. Its death was interpreted as ancestral punishment.

Lena's childcare practices shocked me. I thought I was being normative but later realized her family also believed her a poor mother. Thus I felt disgusted by seeing how Gabriella generally spent the whole day dirty because of dust from their house's dirt floor in Lebi Doti. A nurse visiting them regularly had recommended Lena putting socks on Gabriella's hands to prevent her biting them and consequent infection, but the socks were dirty. The way Lena treated her five-year-old eldest daughter, Gabi, also horrified me. Lena constantly and peremptorily asked her to do domestic chores, like caring for the younger children or buying provisions from neighbours. Gabi had not yet attended school and I felt she should do so because teachers told me how crucial nursery school was for French-Guianese children to learn French.

Over the months, I discovered that many relatives also criticized Lena and felt she was overdependent. These criticisms only surfaced after Gabriella's death. I went to Silvia's house, where everyone gathered in mourning. Lena sat in the living room, wearing black-and-white mourning clothes, surrounded by many relatives, including Silvia and Mora. Lena told me her daughter had undergone surgery when her hand became infected, and never awoke. I immediately thought there 
had been a medical error. However, Lili and Franz's wife provided a different version when I visited them later. They claimed it was Lena's fault because she should have entrusted Gabriella to the State (meaning the children' hospital).

Upon returning to the field a year later, I visited Lena at Midina kampu. She had returned to her Tante's configuration after exclusion from Lili's. Lena rejected Lili's and Franz's accusations: 'They say I killed her, but it was the doctor's fault'. She suggested Franz refused to drive her to the hospital that night, saying she was always bothering him for something. She found a taxi instead. The lack of support from members of her previous configuration was why she had returned to 'her' family in the kampu,. She added she had not entrusted Gabriella to the doctors because they took her first child to Martinique without her permission, where he died, and she could not bury him. She had not wanted that happening again.

However, Lena's support within her Tante's configuration was also limited. Neither Mora nor Silvia had offered accommodation in Saint-Laurent. Her Tante provisionally lent her half a house to stay in with her husband and their children. However, she had to prove willingness to become financially independent. Her husband found a security-guard job in one of Albina's Chinese shops, and she started planting a field near the kampu. She also planned to build a house. Silvia would give her some land she had bought nearby, between the kampu and Albina. Lena was, however, Silvia's second choice; Silvia had wanted to give it to her own daughter, but she already had a house in Saint-Laurent. This shows Lena's marginality within her Tante's configuration. The two river-banks did not share the same status in this transborder configuration. Although living on the French side meant enhanced social-benefit access, Lena had to return to the Surinamese side because of her marginality.

The border territory had two unequal sides. This was clear from people's everyday journeys to different institutions. Lena never considered her move beyond the border permanent. After my kampu visit she crossed to the French side several times visiting relatives or government offices. Her disabled child's death had reduced her chances of getting her residence documents because the hospital's social workers had been supporting her regularization application. However, she still hoped to return to French Guiana. Her eldest daughter, Gabi, was still being schooled there even though she had moved to the kampu. At first, she had entrusted Gabi to a sissa in Saint-Laurent who eventually threw the little girl onto the street, where the police found her. During my visit, Gabi was staying at someone else's house in Albina so she could cross the river every morning for school in French Guiana. A schooling certificate can serve as proof in regularization applications that someone has stayed five years or more on French territory. Lena had not totally relinquished the idea of living on the French-Guianese side. 


\section{National Lines and Urban Planning: Facing Eviction.}

The border also became concrete in Lebi Doti's inhabitants' everyday lives through the denial of land rights. In 2011, French authorities had demolished their fields, asking them to leave. For a long time, urban planners had failed to take into account the presence of many existing residents in designing a huge project for 4,000 social-housing dwellings. Also in 2011, an NGO commissioned a study of 'spontaneous dwellings' in the zone. Helped by aerial images, the authors estimated over 6,000 people lived in the zone and surrounding areas (DEAL Guyane, 2012). The project's implementation implied their eviction. Demolition had occurred at the site where the first buildings were being constructed. During initial groundworks, the project's building company - the Senog, Société d'Economie Mixte de l'Ouest Guyane, which is $80 \%$ municipally owned - had instructed bulldozer drivers to dig very close to existing dwellings aiming to intimidate residents into leaving. Those with French citizenship or French-residence documents were sometimes offered social housing. 'Illegal' immigrants, however, had no right to social housing. Intimidation mostly worked. In 2013, only a few houses remained amidst a flattened space, including Lili’s.

Lili described the bulldozer arriving, their crops being destroyed and how she looked on helplessly. She denounced the injustice of demolition, comparing the country with Suriname, where this would never happen: 'they give you the land, and they cannot demolish your work'. Her son Franz was fighting the clearance, using French law to demonstrate his goodwill and good faith. They showed me photos Franz had taken upon learning his field would be destroyed. Franz recalled the same thing happened when the municipality evicted them from a neighbourhood called Vietnam transferring them to Djakata. The mayor had not come himself but sent his son, as municipal representative, along with his colleagues. This time, however, Franz believed he was well within his rights. In Vietnam, many people were occupying the land, but here he had gone through the official procedure to apply to the French Guiana public development agency (EPAG) for the title deed. This procedure was uncompleted, but he had retained the application receipt, which he showed me proving his goodwill even though he knew it did not constitute a title deed:

When I saw the place, before I cleared it, I went to the EPAG. The agents looked at the map and said, this land belongs to state property, so if I want it, what do I want to do with it? I said I wanted to cultivate the land and build a house, I wanted to live there. They said OK. They gave me a form, I filled it out and sent it. Then I received this receipt. This meant I had to wait a little while.

Franz was illiterate, but knew exactly what the procedure meant. He had recently obtained French nationality having been stateless his whole life - he was born on his mother's kampu, never being 
registered by any State. In 2011, he had tried to go to the tax office to pay the land tax, like his neighbours' to prove occupation, but was told he should have done so long before because it was now impossible with the planned urban-development project.

Franz claimed he knew nothing about the project before 2011, protesting the injustice he was subject to. He argued the EPAG was willing to give him the land but the commune's mayor blocked it: certainly all EPAG land-applications were first unofficially municipally reviewed. He was angry about other Ndyuka people coming to settle on 'his' land without his authorization. Upon seeing the workers demolishing his field, he visited the mayor's son, whom he knew personally. The latter said Franz could receive compensation for his fruit trees and EPAG officials had been sent to count them. Franz saw them but did not know they would destroy everything. He had to accept this meagre consolation and return home. Nevertheless, he continued defending his rights using the register of French administrative law. He was thus arguing (on behalf of his group) their defence in French legal terms even though judicial success appeared slim. French-Guianese power-structures made this procedure nearly impossible: working-class Maroons were marginalized by State officials applying French law in ways providing no chance of winning their right to their land. Franz's action just left Lebi Doti people in a wait-and-see situation, withstanding threat of demolition thanks to their own resources and agriculture. Six years later, Franz was still there, surrounded by new buildings and awaiting a deal to legalize his situation.

In these twin cross-river, cross-border towns, Ndyuka inhabitants negotiated a combination of State opportunities and constraints. They had created a transborder space, connecting Saint-Laurent and Albina, where national hierarchies were in play. The two sides did not have the same value. Compared with Suriname, French Guiana offered the Ndyuka more healthcare, benefits and housing-prospects, but also greater risks around residence documents and denial of land-rights. National borders and social boundaries intertwined with kinship groups. Ndyuka people did not just inhabit single houses but entire configurations, where residents actively engaged with each other based on matriliny. While exchanges and solidarity were evidenced between the evolving housing networks, these ways of dwelling were also structured by tensions. Lena's story shows that belonging to a configuration entailed individual costs. People had to follow certain rules, like proving they would try to become financially independent or be good parents. If someone transgressed, they could be excluded or marginalized. However, in the case of evictions, for example, kinship-ties allowed mobility to the Surinamese side of the river and the capacity to return depending on administrative constraints. These configurations thus provided solidarity resources helping Ndyuka people cope with State constraints. 


\section{References}

Aberley, D (ed.) 1993, Boundaries of home: mapping for local empowerment, New society publ, Philadelphia.

Benoît, C 2015, 'Sans-papiers amérindiens et noirs marrons en Guyane: la fabrication de l'étranger sur le fleuve Maroni', in Moomou, J (ed.), Sociétés marronnes des Amériques: mémoires, patrimoines, identités et histoire du XVIIe au XXe siècles, Ibis Rouge, Matoury (French Guiana).

Collomb, G \& Renault-Lescure, O 2014, 'Setting up Frontiers, Crossing the Border: The Making of Kari'na Tyrewuju', in Carlin, EB, Léglise, I, Migge, B, Tjon Sie Fat, B (eds.), In and Out of Suriname: Language, Mobility and Identity, Brill, Amsterdam.

Colombier, R, Deluc, B, Rachmuhl, V 2012, L'urbanisation spontanée en Guyane: appui à la mise en ouvre de modes d'aménagement alternatifs, Groupe de Recherches et d'Echanges Technologiques, DEAL Guyane, 3 reports.

Douglas, M 1991, 'The Idea of Home: A Kind of Space', Social Research, vol.58; no 1, pp. $287-$ 307.

Glick Schiller, N, Basch, L \& Blanc Szanton, CB 1992, 'Transnationalism: A New Analytic Framework for Understanding Migration', Annals of the New York Academy of Sciences, vol. 645, no $1 ;$ pp. 1-24.

Gollac, S 2003, 'Maisonnée et cause commune: une prise en charge familiale' in Gramain, A \&Weber, F, Charges de famille, La Découverte, Paris.

Heemskerk, M \& de Theije, M 2009, Moving frontiers in the Amazon: Brazilian small-scale gold miners in Suriname, European Review of Latin American and Caribbean Studies, no 87, pp. 5-25.

Hoyaux, AF 2002, 'Entre construction territoriale et constitution ontologique de l'habitant: Introduction épistémologique aux apports de la phénoménologie au concept d'habiter', Cybergeo: European Journal of Geography, 29 May 2002, viewed $3^{\text {rd }}$ March 2021, https://doi.org/10.4000/cybergeo.1824 .

Laëthier, M 2014, 'The Role of Suriname in Haitian Migration to French Guiana: Identities on the Move and Border Crossing', in Carlin, EB, Léglise, I, Migge, B, Tjon Sie Fat, B (eds.), In and Out of Suriname: Language, Mobility and Identity, Brill, Amsterdam.

Marcelin, LH 1996, L'invention de la famille afro-américaine: famille, parenté et domesticité parmi les Noirs du Recôncavo da Bahia, Brésil, PhD Thesis, Universidade Federal do Rio de Janeiro, Museu Nacional, PPGAS, Rio de Janeiro.

Léglise, I, Migge, B 2019, 'Language and identity construction on the French Guiana-Suriname border', International Journal of Multilingualism, pp. 1-15, doi.org/10.1080/14790718.2019.1633332

Motta, E 2014, 'Houses and economy in the favela', Vibrant - Virtual Brazilian Anthropology, vol. 11, no 1, pp.118-158.

Piantoni, F 2009, L'enjeu migratoire en Guyane française: une géographie politique, Ibis rouge, Matoury (French Guiana).

Vernon, D 1992, Les représentations du corps chez les Noirs marrons Ndyuka du Surinam et de la Guyane française, Paris: ORSTOM, 1992.

Whiteford, L 1979, 'The borderland as an extended community', in Kemper, R (ed.), Migration across frontiers: Mexico and the United States, State University of New York at Albany, Institute for Mesoamerican Studies, Albany, pp. 127-137. 